\title{
JÓZEF MACKIEWICZ I SEKTY
}

\author{
GRZEGORZ PEŁCZYŃSKI ${ }^{1}$ \\ (Poznań)
}

Słowa kluczowe: Kresy Wschodnie, mniejszości religijne, protestantyzm

Keywords: Eastern Borderlands, religious minoirities, protestantism

\begin{abstract}
Abstrakt: Grzegorz Pełczyński, JÓZEF MACKIEWICZ I SEKTY. „PORÓWNANIA” 11, 2012, Vol. XI, ss. 327-332, ISSN 1733-165X. Artykuł jest poświęcony pewnej części, wczesnej, reporterskiej twórczości Józefa Mackiewicza. W reportażach napisanych pod koniec lat trzydziestych, przedstawił on protestanckie mniejszości religijne, bujnie rozwijące się wówczas na wschodzie Polski, lecz nie cieszące się pozytywną opinia władz i ludności otaczającej. Mackiewicz stwierdził, że wszystkie zarzuty stawiane owym sektom, są niesłuszne. Uważa on ponadto, że mogą one pozytywnie wpłynąć na stosunki społeczne. Reportaże Mackiewicza o sektach to odosobniony przykład zainteresowania tym tematem w ówczesnej Polsce.
\end{abstract}

Abstract: Grzegorz Pełczyński, JÓZEF MACKIEWICZ AND SECTS. "PORÓWNANIA" 11, 2012, Vol. XI, pp. 327-332, ISSN 1733-165X. The article is dedicated to a part of early reportage work of Józef Mackiewicz. In the reportages written at the end of 1930s, he presented Protestant religious minorities which back then flourished in eastern part of Poland, but which did not have a positive opinion among the authorities and other peoples. Mackiewicz stated that all the accusations towards those sects were groundless. He also claimed that they can positively influence social relations. Mackiewicz's reportages on sects was an isolated case of interest in this topic in Poland of those times.

Kresy Wschodnie stanowiły terytorium wielce zróżnicowane pod względem religijnym. Żyli tam obok siebie prawosławni i katolicy, prócz tego byli też żydzi. W niektórych miejscach spotykało się grekokatolików, Ormian-katolików, staroobrzędowców, luteran i kalwinistów, wreszcie karaimów i muzułmanów. Wszystkie te społeczności, choć bardzo różne i niekiedy skonfliktowane, były jednak czymś znanym, swojskim, bo istniejącym od wieków na wschodnich ziemiach niegdysiejszej Rzeczypospolitej. Jednakże pod koniec wieku XIX zaczęły się tam pojawiać

\footnotetext{
${ }^{1}$ Corrspondence Address: gregory@amu.edu.pl
} 
rozmaite grupy religijne, zaliczające się do protestantyzmu, które na ogół nazywano sektami ${ }^{2}$. Stanowiły one całkiem nowe zjawisko na tym obszarze ${ }^{3}$. A obszar ten, oprócz jego południowej części, należał wówczas do Rosji, gdzie od połowy XIX wieku, tysiące osób porzucało prawosławie, by przyłączyć się do któregoś z ugrupowań protestanckich ${ }^{4}$. Tak działo się też na Kresach Wschodnich. Fenomen ten trwał jeszcze w okresie międzywojennym zarówno w Związku Radzieckim, jak również we wschodniej Polsce.

Polska nauka raczej nie zainteresowała się tym zagadnieniem, w przeciwieństwie do rosyjskiej. Może wynikało to z faktu, iż owe sekty przyciągały głównie ludność prawosławną, a więc też najczęściej niepolską. Zwrócili jednak na nią uwagę rozmaici publicyści, szczególnie z kręgów kościelnych, aczkolwiek nie przyczynili się zbytnio do ich poznania. W swoich tekstach zazwyczaj tylko niezbyt udolnie polemizują z zasadami doktrynalnymi sekt bądź tylko traktują je jako sensację.

Inaczej postąpił Józef Mackiewicz, młody wileński dziennikarz, pracujący w konserwatywnym dzienniku "Słowo”, który założył i redagował jego starszy brat, Stanisław Mackiewicz Cat. Dogłębnie zbadał on zjawisko sekciarstwa i opisał w cyklu reportaży, który później zamieścił w Buncie rojstów, swej debiutanckiej książce wydanej w 1938 roku$^{5}$. Młodszy z braci Mackiewiczów przedsięwziął kilka reporterskich podróży do kresowych wiosek i miasteczek, aby porozmawiać z członkami sekt w miejscach, w których toczy się ich życie ${ }^{6}$. Przedtem zebrał wszelkie stereotypy dotyczące tych grup religijnych. Obcując zaś z nimi osobiście, zamierzał sprawdzić, ile w nich prawdy.

Pierwszy z tych stereotypów mówił, że sekciarze źle interpretują Pismo Święte, że ich wiara jest błędna. J. Mackiewicz przytacza w reportażu Szukamy prawdy w powiecie wileńskim słowa ks. dziekana Śnieżki:

Cóż oni mogą mieć za korzyść z Ewangelii. Pismo Święte wymaga nauki, studjów teologicznych [...]. Stoi w Piśmie Świętym naprzykład »Bracia i siostry«, oni to komentują tak, że Chrystus miał braci i siostry, co jest wyraźną herezją. Ciągle, we wszystkim powołują się na Ewangelję, nie rozumiejąc jej i tumaniąc ludzi. Swojego czasu J.E. Arcypasterz zarządził był nawet czytanie Ewangelji w kościele po nabożeństwie. Ale para-

2 Używanie terminu "sekta” nastręcza wielu trudności. W socjologii religii jest on zupełnie neutralny i oznacza grupę religijną powstałą wskutek niedawnego odłączenia od innej grupy religijnej. Potocznie tym mianem określa się społeczności religijne z bardzo różnych względów negatywnie oceniane przez otoczenie. Zob. E. Troeltsch, Kościót a sekta. Przeł. W. Adamek (w:) Socjologia religii. Red. F. Adamski. Kraków 1984, s. 104-109.

${ }^{3}$ G. Pełczyński, Restauracja "Kresowa”. Kraków 2011, s. 169-170.

${ }^{4}$ S. Sawinski, Istorija evangle'skich christian-baptistov Ukrainy, Rossii, Belorussii. Sankt-Peterburg 1999, s. 92-159.

${ }^{5}$ W. Bolecki, Ptasznik z Wilna. O Józefie Mackiewiczu (zarys monograficzny). Kraków 2007, s. 146-149.

${ }^{6}$ Ibidem, s. 123. 
fjanie, nawet z pośród inteligencji, jej nie rozumieją, to jest rzecz trudna. Nic pozatem dziwnego, że sekciarze ją paczą ${ }^{7}$.

Ta opinia zdaje się dobrze wyrażać ówczesny stosunek Kościoła katolickiego do samodzielnego czytania Biblii przez zwykłych wiernych. Jest ona zaś sprzeczna z protestancką praktyką. Protestanci wszystkich odłamów bowiem uważali zawsze regularną lekturę Pisma Świętego wręcz za konieczną.

Reportażysta następnie rozmawiał z ewangelicznymi chrześcijanami, baptystami, zielonoświątkowcami, choć głównie z ich duchownymi i za każdym razem przekonywał się, że są to ludzie, którzy to, w co wierzą, potrafią uzasadnić, posługując się Biblią. Mackiewicz nie ocenia ich doktryny z punktu widzenia swoich przekonań religijnych. Pokazuje jednak, że członkowie sekt dobrze ją znają i że na pewno nie jest ona prymitywna.

Z kolei według innego stereotypu sekciarze są finansowani przez współwyznawców z Niemiec i Ameryki. Ponoć za samo wstąpienie do sekty otrzymywało się od 1 do 5 dolarów. Mackiewicz stwierdził tylko, że z zagranicznych Kościołów otrzymują oni dość niewielką pomoc i to niekoniecznie w postaci pieniędzy, bo przede wszystkim literatury religijnej przeznaczonej do bezpłatnej dystrybucji.

Jednakże odwiedzając ich domy zauważa często ich schludność i względny dostatek. Ale nie przyczynili się do tego bogaci współwyznawcy z zagranicy. Ich wiara nakłaniała bowiem do pracowitości i trzeźwości, do wzajemnej pomocy, a skutkiem tego był brak nędzy wśród członków protestanckich zborów.

Poza tym dość powszechnie wątpiono w ich lojalność wobec państwa. Opowiadano nawet, że podczas wojny byli szpiegami niemieckimi. Teraz zaś nie chcą służyć w polskiej armii. Mackiewicz pytał o to swoich rozmówców. Niejaki Minajło z Wilejki, stolarz i kaznodzieja baptystyczny stwierdził: „Przecież powiedziano jest, że »każda władza od Boga pochodzi«... My słuchamy władzy. A jeżeli trzeba na wojnie zabijać... To już zależy od sumienia. Jak kto czuje, tak niech robi, jeżeli władza każe"8. A zatem ich poglądy na temat służby wojskowej najprawdopodobniej nie odbiegały od tego, co o niej sądziła większość mieszkańców kraju.

Dzięki spotkaniom z członkami nowych mniejszości protestanckich, Mackiewicz przekonał się więc, że rozpowszechnione stereotypy są w dużej mierze kłamliwe. Ich wiara jest poważna i zasługuje na szacunek. Nawrócili się na nią z pewnością nie ze względu na korzyści materialne. A poza tym za nieposzlakowaną uznać należy ich lojalność obywatelską.

Autor przekonuje się o wiarygodności swych innowierczych rozmówców, nabrawszy dobrego mniemania o ich charakterach. Że są uczciwi, szczerzy, gotowi

\footnotetext{
${ }^{7}$ J. Mackiewicz, Bunt rojstów. Warszawa 1990, s. 8 - ten, jak też inne cytaty według wersji orygi-

${ }^{8}$ Ibidem, s. 8.
} nalnej. 
do poświęceń. A przede wszystkim nie są tacy, jak o nich często mówią katolicy i prawosławni.

Mackiewicz szkicuje portrety kilku sekciarzy. W kilku słowach potrafi przedstawić charakter człowieka, który odważył się żyć inaczej niż jego sąsiedzi. Tak pisze o wspomnianym już Minajle: „Mały, golona głowa, o bystrych, głęboko osadzonych oczkach”. Pyta go na czym polega jego religia. „Na nauce Chrystusa odpowiada bez zająknienia. - My żyjemy tak, jak Chrystus przykazał. Czytamy Ewangelję i tak postępujemy"'.

W reportażu zatytułowanym Radoszkowicki biskup »Paitidiesiatnikow « został opisany niejaki Niedźwiecki. Wbrew tytułowi nie był on biskupem, gdyż u piatidiesiatników, jak po rosyjsku nazywa się zielonoświątkowców, raczej nie ma takiego urzędu. Był on po prostu głównym kaznodzieją na powiaty Wołożyński, Mołodeczański, Wilejski, Postawski i Dziśnieński. Na całym tym obszarze krążyły o nim najróżniejsze opinie, z przewagą jednakże negatywnych. Mackiewicz określa go jako człowieka sympatycznego i szczerego. „Niedźwiecki jest - pisze - w pojęciu tego słowa "salonowem", takim sobie pól-inteligentem, ale jakże on zna Pismo Święte! na pamięć poprostu. Mówi po łacinie całą Mszę Świętą, zna liturgikę zarówno prawosławną, jak katolicką" 10 .

Pobyt w domu Niedźwieckiego wydaje się Mackiewiczowi niezwykłym przeżyciem. Jest on niewątpliwie wstrząśnięty faktem pojawienia się sacrum w całkiem zwyczajnych okolicznościach:

Niedźwiecki nie wypuszcza z domu bez poczęstunku. Śniadanie już podane. Chleb, bułki, konfitury, masło, jaja, herbata, cukier i jakieś słodkie sucharki... Gospodarz wstaje nagle i mówi modlitwę przed spożyciem posiłku. Modlitwa, jak się zdaje, na poczekaniu skomponowana i dostosowana do okoliczności. Wszyscy domownicy w takiej chwili wstają również. W domu robi się cisza. Dziewczyna, szatkująca kapustę w sieni, przerywa robotę ${ }^{11}$.

W domu zielonoświątkowego kaznodziei Mackiewicz spotyka Gancweicha z Gdańska. To „młody żydek, o wyraźnie semickiej twarzy, kręconych włosach, czystym kołnierzyku z czarną muszką, $\mathrm{w}$ granatowym dobrym garniturze i zdeptanych butach. Jest bardzo grzeczny, mówi po polsku z cudzoziemskim akcentem, a do Niedźwieckiego często zwraca się w języku angielskim"12. Zajmuje się nawracaniem Żydów. W tej działalności jest wyjątkowo osamotniony. Żydzi nie chcą go słuchać, uważając, że został misjonarzem ze względu na korzyści materialne. $Z$ kolei nie-Żydzi, chociaż uważają go za „brata”, pamiętają wciąż o jego pochodzeniu.

\footnotetext{
9 Ibidem.

10 Ibidem, s. 18.

11 Ibidem, s. 18 .

12 Ibidem, s. 16.
} 
W czasie jednej z reporterskich podróży Mackiewicza wiózł zielonoświątkowiec Kraczkowski. Autor poświęca mu tekst pod tytułem Noc na Czarnym Trakcie. Jego woźnica chętnie wdał się z nim w rozmowę na tematy religijne. Będąc człowiekiem z pogranicza religijnego, bardzo go one frapowały. Jego wypowiedzi wileński dziennikarz przytacza, bacząc na ich gwarową formę:

$\mathrm{Z}$ rannych lat przyszła do mnie zastanowienia taka. Wielkie było prześladowanie katolików. Pop wszystko pyta: a czy do kościoła nie chodzisz? Powiesz, że zachodzisz, to kiedy narzuci się, że to wielki grzech, mówi. Dzisiejszo poro, jak panu wiadomo, wszystko odmieniło się i ksiądz teraz z ambony, czyli też na spowiedzi, pyta: czy do cerkwi nie chodzisz? I znów teraz to grzech. A cóż tam w kościele, czy cerkwi złego! Ludzie modlą się, Boga, można powiedzieć, chwalo. Czemu nie zapyta, czy do karczmy nie chodzisz?! Wódka czy pijesz!13.

Z dalszej rozmowy wynika, że Kraczkowski rozczarował się do zewnętrznych obrządków religijnych. Nie mógł się też pogodzić z faktem złego prowadzenia ludzi mieniących się chrześcijanami. W rezultacie przystał do zielonoświątkowców.

Reportaż kończy scena, w której autor wciąż jedzie nocą po litewskich drogach i bezdrożach, słuchając woźnicy głośno śpiewającego psalmy.

Mackiewicza interesują też sekciarskie domy modlitw. Pewni ewangeliczni chrześcijanie spotykają się w zwykłej chacie, której jedna z izb służy jako miejsce zebrań:

Stoją w niej ławki ustawione jak w szkole, na ścianach wyjątki z Pisma Świętego. Dużo ich. Pośrodku z czerwonego papieru wycięte litery na białym tle: „Krow Isusa Christa ocziszczajet nas od wsiakowo griecha".

Naprzeciw ławek mała katedra. Nie przeszkadza, że w rogu izby stoją garnki z mlekiem i śmietaną. Na oknach broszury w języku rosyjskim i polskim. Na ścianach sztuczne kwiaty i girlandy. Tak wygląda dom modlitwy w głuchej, zapadłej wioszczynie białoruskiej ${ }^{14}$.

Reportażysta zwraca też uwagę na to, co się w tych wnętrzach dzieje. Nabożeństwa protestanckie różnią się od katolickich i prawosławnych, szczególnie zaś zielonoświątkowe. Zielonoświątkowcy to ludzie pragnący bardzo bliskiego kontaktu z Duchem Świętym ${ }^{15}$. Ten kontakt możliwy jest w trakcie ekstazy, której doświadczają wierni w trakcie swych spotkań modlitewnych. Mackiewicz opisuje jedno z takich spotkań:

Byłem na takiej modlitwie, gdzie nic zdrożnego się nie dzieje. Ludzie przeważnie starsi, kobiety i mężczyźni, siedzą w ławkach i słuchają czytania i komentowania Ewange-

\footnotetext{
${ }^{13}$ Ibidem, s. 21.

14 Ibidem, s. 10.

15 Zob. Z. Pasek, Ruch zielonoświątkowy. Próba monografii. Kraków 1992, s. 47-85.
} 
lji. Następnie śpiewają. Śpiewają psalmy po rosyjsku, przeciągle, smutno, na melodję powłóczystej pieśni białoruskiej. Później się modlą głośno, chaotycznie, oderwanie. W tej chwili dopiero opanowuje ich ekstaza. Chłop stary, brodaty, mówi coś wpatrzony $\mathrm{w}$ werset Ewangelji na ścianie, głowa mu się trzęsie, czasami zębami dzwoni, otula się świtką, jakby mu zimno było i woła nagle: „ałaj, ałaj, ałaj”. - Co to znaczy? - Boga chwali. - Dlaczego w taki sposób? - Taki mu Duch święty zesłał język ${ }^{16}$.

Autor poznanych grup religijnych nie ocenia negatywnie. Wręcz przeciwnie, uważa je za społeczności, które mogą dodatnio wpłynąć na stosunki społeczne na Kresach Wschodnich, przeżywających wszakże liczne konflikty spowodowane kryzysem ekonomicznym, sporami narodowościowymi, bliskością granicy wrogiego państwa. Autor zwraca uwagę na fakt, iż literatura metodystów, baptystów, ewangelicznych chrześcijan i zielonoświątkowców wyparła w znacznej mierze bibułę komunistyczną. Poza tym, ponieważ Cerkiew na Kresach, po rewolucji październikowej nie wspierana przez carat, a raczej lekceważona $\mathrm{w}$ państwie z większością katolicką, miała poważne problemy ze swym funkcjonowaniem, sekty zaspokajały potrzeby religijne pewnej części jej wiernych, do których ona już nie umiała czy nie mogła dotrzeć.

Fenomen opisany przez Mackiewicza w części Buntu rojstów przetrwał drugą wojnę światową. Po jej zakończeniu, po przyłączeniu Kresów do Związku Radzieckiego, zbory przez niego odwiedzane opuścili wierni polskiej narodowości, wyjeżdżając do Polski w nowych granicach. Tych, którzy pozostali, przyłączono do Związku Ewangelicznych Chrześcijan-Baptystów, będącego unią kilku ugrupowań ewangelicznych, ściśle kontrolowaną przez władze komunistyczne.

Józef Mackiewicz również wyjechał, ale nie do Polski, tylko na Zachód. Stał się wybitnym, aczkolwiek kontrowersyjnym ${ }^{17}$ pisarzem emigracyjnym. Do tematyki związanej $\mathrm{z}$ sektami już nie powrócił. Interesował się jednak religią $\mathrm{w}$ aspekcie politycznym. W latach siedemdziesiątych opublikował dwie książki: W cieniu krzyża i Watykan w cieniu czerwonej gwiazdy, w których wytykał Kościołom zbytnią uległość wobec komunizmu ${ }^{18}$. Można wysunąć przypuszczenie, że doświadczenia z chrześcijaństwem mniej oficjalnym, bardziej uduchowionym, jakie spotykał przed wojną w sektach, sprawiły, iż z krytycyzmem spoglądał na Kościoły większościowe.

\footnotetext{
16 Ibidem, s. 13.

17 G. Pełczyński, Bracia Mackiewiczowie. „Znad Wilii” 2011, nr 1, s. 60-61.

18 W. Bolecki, op. cit, s. 720-727.
} 